Akses Online :

http://jurnal.iicet.org

Dipublikasikan oleh :

Indonesian Institute for Counseling, Education and Therapy (IICET)

Info Artikel:

Diterima: 06/27/2019

Direvisi: 08/02/2019

Dipublikasikan: 10/01/2019

\title{
Pengaruh bimbingan kelompok teknik permainan simulasi terhadap peningkatan komunikasi reseptif siswa tunarungu
}

\author{
Erlin Fitria $^{1}$, Dian Yudhawati ${ }^{2}$ \\ ${ }^{12}$ Universitas Teknologi Yogyakarta
}

\begin{abstract}
There are several problems faced by 14 deaf students as the subject of this research. They get difficulties in understanding long sentences, connotative meaning, and they lack vocabulary. Their inability to hear makes them rely on their vision to gather information. Considering the reason for their difficulties, visual and attractive learning media are needed for deaf students. Group guidance on simulation game technique is a counseling guidance service that directs students to reflect daily activities in the form of games using physical media such as blue cards, OK cards and chance cards. In the group guidance of the simulation game technique, students learn to understand the new vocabulary of the role played and can gain vocabulary. The more vocabulary mastered will support students' ability to have receptive communication. To prove the hypothesis that the group guidance of simulation game technique influences improves receptive communication of deaf students in SLB.B Wiyata Dharma 1, the Mann Whitney U Test analysis is used. The result shows that the group guidance of the simulation game technique impacts increasing the receptive ability of deaf students. Therefore, group guidance on simulation game techniques can an alternative learning media to improve receptive communication for deaf students.
\end{abstract}

Keywords: Group guidance, simulation game technique, receptive communication, deaf student

(c) (i) This is an open access article distributed under the Creative Commons Attribution License, which permits unrestricted use,

\section{PENDAHULUAN}

Penyandang tunarungu adalah seseorang yang memiliki kesulitan dalam mendengar karena kerusakan yang terjadi pada organ pendengaran. Somad (2016) mengartikan ketunarunguan atau hearing impairment adalah satu istilah umum yang menggambarkan semua derajad dan jenis kondisi tuli (deafness) terlepas dari penyebab dan usia kejadiannya. Hernawati, (2007) mendefinisikan anak tunarungu yakni anak yang mengalami gangguan pada organ pendengarannya sehingga mengakibatkan ketidakmampuan mendengar, mulai dari tingkatan yang ringan sampai yang berat, yang diklasifikasikan ke dalam tuli (deaf) dan kurang dengar (hard of hearing). Hallahan, D. P. \& Kauffman, (1991) mengemukakan bahwa orang yang tuli (a deaf person) adalah orang yang mengalami ketidakmampuan mendengar, sehingga mengalami hambatan dalam memproses informasi bahasa melalui pendengarannya dengan atau tanpa menggunakan alat bantu dengar (hearing aid), sedangkan orang yang kurang dengar ( a hard of hearing person) adalah orang yang biasanya menggunakan alat bantu dengar, sisa 
pendengarannya cukup memungkinkan untuk keberhasilan memproses informasi bahasa, artinya apabila orang yang kurang dengar tersebut menggunakan hearing aid, masih dapat menangkap pembicaraan melalui pendengarannya. Anak tunarungu secara fisik memiliki karakteristik yang sama seperti anak normal, anak tunarungu juga memiliki kebutuhan dan tugas-tugas perkembangan yang sama dengan anak-anak normal, bahkan anak tunarungu cenderung memiliki motivasi yang bagus dalam belajar, namun memiliki beberapa keterbatasan akibat ketidakmampuan dalam mendengar (Tarmansyah, 2014). Penelitian yang dilakukan oleh Suparno, (2001) anak tunarungu terbatas pada peniruan bahasa secara visual (penglihatan), yaitu melalui gerakgerik dan isyarat, sedangkan peniruan bahasa melalui pendengaran (auditif) umumnya tidak dapat dilakukan. Padahal peniruan bahasa melalui pendengaran inilah yang paling dominan sebagai pembentuk bahasa pada seorang anak. Pujiwati (2012) menjelaskan dampak dari terhambatnya perkembangan bahasa bisa mengakibatkan anak tunarungu kurang memiliki persyaratan pokok komunikasi yang berbentuk lisan, sehingga dalam mengekspresikan perasaan, pikiran dan kehendaknya banyak mengalami kendala. Kesulitan dalam mengekspresikan perasaan, pikiran dan kehendak ini membuat anak tunarungu sulit untuk melakukan komunikasi secara verbal dengan orang yang terbiasa berkomunikasi verbal. Idealnya dalam proses komunikasi, komunikan dapat memahami informasi yang disampaikan oleh komunikator (komunikasi reseptif) kemudian komunikan dapat memberikan umpan balik pada komunikator (komunikasi ekspresif). Efendi, (2009) anak tunarungu juga seringkali tampak frustasi, tidak aman, bimbang dan ragu-ragu terhadap keberadaan dirinya. Keadaan tersebut dikarenakan faktor lingkungan mulai dari keluarga, teman sebaya, maupun masyarakat sekitar yang memberikan tekanan. Tekanan yang dimaksud adalah lingkungan tidak mampu memahami kebutuhan anak tunarungu sehingga mengharuskan anak tunarungulah yang melakukan penyesuaian dengan orang normal, padahal idealnya orang normal lah yang berusaha melakukan penyesuaian terhadap anak tunarungu, bukan sebaliknya.

Walaupun anak tunarungu memiliki keterbatasan dalam pengembangan bahasa namun tetap dapat melakukan komunikasi secara verbal jika banyak mendapatkan latihan, hal ini juga diungkapkan oleh Sari \& Praherdhiono (2014) bahwa anak dengan kesulitan mendengar atau tunarungu masih tetap memiliki kemampuan berbahasa sehingga apabila kita melatih atau mengembangkan cara berkomunikasi pada anak yang memiliki hambatan dalam bidang pendengaran, tetap ada kemungkinan anak tersebut dapat mengucapkan huruf dan kata. Mutiara, (2013) media yang diperuntukkan anak tunarungu harus banyak melibatkan indera penglihatan dibanding indera lainnya Hal ini dikarenakan anak tunarungu menggunakan indera penglihatan sebagai indera dominan yang digunakan untuk proses menangkap informasi. Fatimah (2012) mengemukakan, perlu diberikan solusi untuk membantu siswa tunarungu agar dapat meningkatkan kemampuan dalam memahami dan mengartikan pesan dari orang lain agar siswa dapat melakukan hubungan sosial dengan masyarakat luas.

Syarah Aini Fajrin \& Hernawati, (2018) mengemukakan bahwa media visual dapat memperlancar pemahaman siswa tunarungu (misalnya melalui elaborasi struktur dan organisasi) serta dapat memperkuat ingatan. Hal senada disampaikan oleh Witri Erdiawati S.R, (2016) bahwa dampak dari keterbatasan untuk mendengar ini, siswa tunarungu sangat membutuhkan media belajar yang bersifat visual, bersifat menarik, dan bersifat kongkret seperti penelitian yang dilakukan Rachmawati, (2017), flash card sangat sesuai dengan masa perkembangan anak usia dini, selain mendukung pola belajar anak secara visual juga memberikan efek menyenangkan pada anak. Penggunaan media flash card ini mendukung perkembangan rasa percaya diri pada anak serta membentuk motivasi belajar yang menyenangkan. Hal itu diperlukan karena pada anak tunarungu sering mengalami kesulitan mengenal huruf dikarenakan kekurangan dalam indera pendengaran. Penelitian lain tentang penggunaan media visual sebagai media pembelajaran untuk siswa tunarungu dilakukan oleh Syarah Aini Fajrin \& Hernawati, (2018) komik dapat menggantikan kata verbal dan mengkongkritkan yang abstrak. Komik yang berisi ilustrasi kartun dan animasi ini dapat memudahkan anak dalam menerima informasi dan anak dapat mendeskripsikan isi bacaan. Penelitian lainnya yang dilakukan Fillina, (2013) mengemukakan bahwa metode role playing merupakan salah satu pendekatan yang dapat ditempuh untuk mengatasi kesulitan yang terjadi dalam pembelajaran siswa tunarungu. Melalui metode role playing, para siswa mencoba mengkesplorasikan masalah-masalah hubungan antar manusia dengan cara memperagakannya. Penelitian penelitian tersebut menggunakan media fisik dan bersifat visual untuk membantu siswa tunarungu belajar memahami kosakata.

Peneliti menggunakan alternative media pembelajaran visual lainnya yakni bimbingan kelompok teknik permainan simulasi. Bimbingan kelompok menurut Rusmana, (2009) adalah proses pemberian bantuan kepada individu melalui suasana kelompok yang memungkinkan setiap anggota untuk berpartisipasi aktif dan berbagi pengalaman dalam upaya pengembangan wawasan, sikap dan ketrampilan yang diperlukan dalam upaya pengembangan pribadi. Prayitno, (2004) bimbingan kelompok mengaktifkan dinamika kelompok untuk 
membahas berbagai hal yang berguna bagi pengembangan pribadi dan pemecahan masalah individu yang menjadi peserta kegiatan kelompok. Salah satu teknik dalam bimbingan kelompok adalah permainan simulasi. Menurut Romlah, (2013) teknik permainan simulasi adalah teknik yang menggabungkan antara teknik bermain peran dan teknik diskusi. Dalam bimbingan kelompok teknik permainan simulasi, siswa didorong untuk terlibat secara aktif merefleksikan realitas kehidupan sehari-hari melalui suasana bermain dalam kelompok yang menggembirakan. Penggunaan teknik permainan (games) dalam kegiatan bimbingan kelompok mempunyai banyak fungsi selain lebih dapat memfokuskan kegiatan bimbingan kelompok terhadap tujuan yang ingin dicapai, juga dapat membangun suasana dalam kegiatan bimbingan kelompok lebih bergairah, dan tidak cepat membuat siswa jenuh mengikutinya (Anita Dewi Astuti, Sugiyo, 2013). Dengan bimbingan kelompok teknik permainan simulasi siswa diarahkan untuk dapat belajar memahami kosakata baru dengan cara merefleksikan kegiatan sehari-hari menggunakan media penunjang seperti kartu beberan, kartu kesempatan dan kartu oke. Semua alat dalam bimbingan kelompok teknik permaian simulasi tersebut berbentuk fisik. Tujuan dalam penelitian ini adalah menganalisa pengaruh dari bimbingan kelompok teknik permainan simulasi terhadap komunikasi reseptif siswa tunarungu.

\section{METODE}

Metode penelitian yang digunakan adalah penelitian quasy experimental dengan rancangan randomized control group pretest-posttest desain. Peneliti memilih jenis penelitian ini bertujuan untuk mengetahui pengaruh bimbingan kelompok teknik permainan simulasi terhadap komunikasi reseptif siswa tunarungu. Data diperoleh sebelum dan sesudah dilakukannya perlakuan pada kelompok eksperimen. Kelompok kontrol tidak diberikan perlakuan tetapi diukur dalam pretest dan posttest. Instrumen yang dipakai adalah angket komunikasi reseptif yang dibuat oleh peneliti dan digunakan untuk mengukur tingkat komunikasi reseptif siswa tunarungu dan panduan observasi.

Sampel yang digunakan dalam penelitian ini adalah 14 siswa tunarungu dengan terbagi menjadi kelompok eksperimen berjumlah 7 siswa dan kelompok kontrol berjumlah 7 siswa. Teknik sampling yang digunakan adalah teknik non probably sampling, puposive sampling. Teknik analisis data dengan uji mann whitney u test karena pada penelitian ini digunakan untuk menguji hipotesis komparatif kelompok sampel yaitu kelompok eksperimen dan kelompok kontrol.

\section{HASIL}

Subyek penelitian ini berjumlah 14 orang yang dikelompokkan dalam kelompok eksperimen dan kelompok kontrol. Pretest dan posttest dilakukan dengan memberikan angket komunikasi reseptif yang telah dimodifikasi dan dikonsultasikan dengan pengajar di SLB.B Wiyata Dharma 1. Selama pelaksanaan pretest dan posttest, siswa diminta menjawab pernyataan-pernyataan yang tertuang dalam angket. Hasil pengumpulan data pretest dan posttest yang menunjukkan skor kemampuan komunikasi reseptif tercantum pada tabel 1 di bawah ini,

\section{Tabel 1. Skor Pretest dan Posttest Komunikasi Reseptif Siswa Tunarungu}

\begin{tabular}{cccccc} 
Subyek & Pretest & Posttest & Total & Indeks Gain & Kelompok \\
\hline $\mathbf{1}$ & 79 & 86 & 165 & 0,082 & Eksperimen \\
$\mathbf{2}$ & 120 & 133 & 253 & 0,295 & \\
$\mathbf{3}$ & 116 & 139 & 255 & 0,479 & \\
$\mathbf{4}$ & 122 & 149 & 271 & 0,642 & \\
$\mathbf{5}$ & 73 & 103 & 176 & 0,329 & \\
$\mathbf{6}$ & 119 & 127 & 246 & 0,17 & \\
$\mathbf{7}$ & 117 & 131 & 248 & 0,297 & \\
$\mathbf{8}$ & 68 & 80 & 148 & 0,125 & \\
$\mathbf{9}$ & 81 & 86 & 167 & 0,06 & \\
$\mathbf{1 0}$ & 75 & 85 & 160 & 0,112 & \\
$\mathbf{1 1}$ & 79 & 87 & 166 & 0,094 & \\
$\mathbf{1 2}$ & 68 & 90 & 158 & 0,229 & \\
$\mathbf{1 3}$ & 81 & 92 & 173 & 0,132 & \\
$\mathbf{1 4}$ & 87 & 103 & 190 & 0,2 & \\
\hline
\end{tabular}


Berdasarkan tabel 1 diketahui bahwa pada kelas ekperimen sebanyak 4 orang mengalami peningkatan dengan kategori rendah, sebanyak 3 orang mengalami peningkatan dengan kategori rata-rata. Untuk kelas kontrol, seluruh subyek mengalami peningkatan dengan kategori rendah.

Tabel 2. Distribusi Data Kemampuan Komunikasi Reseptif Siswa Tunarungu Kelompok Kontrol

\begin{tabular}{ccccc} 
No & Kemampuan Komunikasi Reseptif & Skor Minimal & Skor Maksimal & Mean \\
\hline $\mathbf{1}$ & Pretest & 68 & 87 & 77 \\
$\mathbf{2}$ & Posttest & 80 & 103 & 89 \\
\hline
\end{tabular}

Berdasarkan tabel 2 diketahui bahwa jumlah mean posttest lebih besar dibandingkan jumlah mean pretest, yakni mean pretest berjumlah 77 dan mean posttest berjumlah 89 .

Tabel 3. Hasil Kategorisasi Kemampuan Komunikasi Reseptif Siswa Tunarungu "Kelompok Kontrol"

\begin{tabular}{ccc} 
Kategori & Pre & Post \\
\hline Tinggi & 1 & 1 \\
Sedang & 4 & 5 \\
Rendah & 2 & 1 \\
\hline
\end{tabular}

Berdasarkan tabel 3, dapat diketahui bahwa hasil pretest kelompok kontrol untuk kategori tinggi sebanyak 1 siswa, untuk kategori sedang, 4 siswa, untuk kategori rendah sebanyak 2 siswa. Sedangkan hasil posttest kategori tinggi 1 siswa, sedang 4 siswa dan tinggi 1 siswa. Tidak terdapat kenaikan yang signifikan dari hasil pretest dan posttest kelompok kontrol, hanya 1 siswa yang meningkat kemampuan dalam berkomunikasi reseptif yakni dari kategori rendah ke sedang.

Tabel 4. Distribusi Data Kemampuan Komunikasi Reseptif Siswa Tunarungu "Kelompok Eksperimen"

\begin{tabular}{ccccc} 
No & Kemampuan Komunikasi Reseptif & Skor Minimal & Skor Maksimal & Mean \\
\hline $\mathbf{1}$ & Pretest & 73 & 122 & 106 \\
$\mathbf{2}$ & Posttest & 86 & 149 & 124 \\
\hline
\end{tabular}

Berdasarkan tabel 4 dapat dilihat bahwa skor mean pretest kelas eksperimen lebih tinggi dibandingkan skor mean posttest yaitu $124>106$.

Tabel 5. Hasil Kategorisasi Kemampuan Komunikasi Reseptif Siswa Tunarungu "Kelompok Eksperimen"

\begin{tabular}{ccc} 
Kategori & Pre & Post \\
\hline Tinggi & - & 1 \\
Sedang & 5 & 5 \\
Rendah & 2 & 1 \\
\hline
\end{tabular}

Berdasarkan tabel 5 dapat diketahui pada posttest kelompok eksperimen sebanyak 1 siswa memiliki kemampuan komunikasi reseptif yang tinggi, 5 siswa memiliki kemampuan komunikasi reseptif sedang dan 1 siswa memiliki komunikasi reseptif yang rendah. Ada 2 orang siswa yang mengalami kenaikan kategori yakni 1 siswa meningkat dari rendah ke sedang dan 1 siswa meningkat dari sedang ke tinggi.

\section{PEMBAHASAN}

Hasil analisis data dan pengujian hipotesis pada 14 siswa tunarungu baik kelompok kontrol maupun kelompok eksperimen menunjukkan perbedaan skor sebelum dan sesudah diberikan perlakuan. Pada kelompok eksperimen ada 2 orang siswa yang mengalami kenaikan kategori yakni 1 siswa meningkat dari rendah ke 
sedang dan 1 siswa meningkat dari sedang ke tinggi. Sedangkan untuk kelompok kontrol terdapat peningkatan 1 siswa dari kategori rendah menjadi sedang. Masalah komunikasi reseptif yang dialami oleh 14 siswa tunarungu yang menjadi subyek penelitian diantaranya sulit untuk mengartikan ungkapan-ungkapan dan kata-kata yang abstrak (idiomatik), sulit memahami kalimat-kalimat yang panjang, sulit memahami arti kiasan.

Ada 2 kelompok yang menjadi subyek dalam penelitian ini, yaitu kelompok eksperimen dan kelompok kontrol. Kelompok eksperimen adalah kelompok yang diberikan perlakuan oleh peneliti yakni dengan menggunakan bimbingan kelompok teknik permainan simulasi. Dalam bimbingan kelompok teknik permainan simulasi ini siswa tunarungu diarahkan untuk merefleksikan realitas kehidupan sehari-hari melalui suasana bermain. Bermain dengan teman-teman sebaya dapat membuat anak belajar dalam membangun hubungan sosial dengan anak-anak lainnya, selain itu dalam kegiatan bermain ini anak dapat lebih memahami dan mengerti maksud dari tindakan yang dilakukan oleh orang lain, lebih peka terhadap ekspresi wajah, dan gerakan tubuh sehingga dapat lebih memahami maksud yang disampaikan oleh lawan mainnya. Peneliti menyiapkan beberapa sarana untuk pelaksanaan bimbingan kelompok teknik permainan simulasi diantaranya adalah beberan, kartu oke, kartu kesempatan, dadu, kubik dan tanda pengenal. Berikut adalah media yang dibuat peneliti sebagi sarana yang digunakan dalam bimbingan kelompok teknik permainan simulasi:

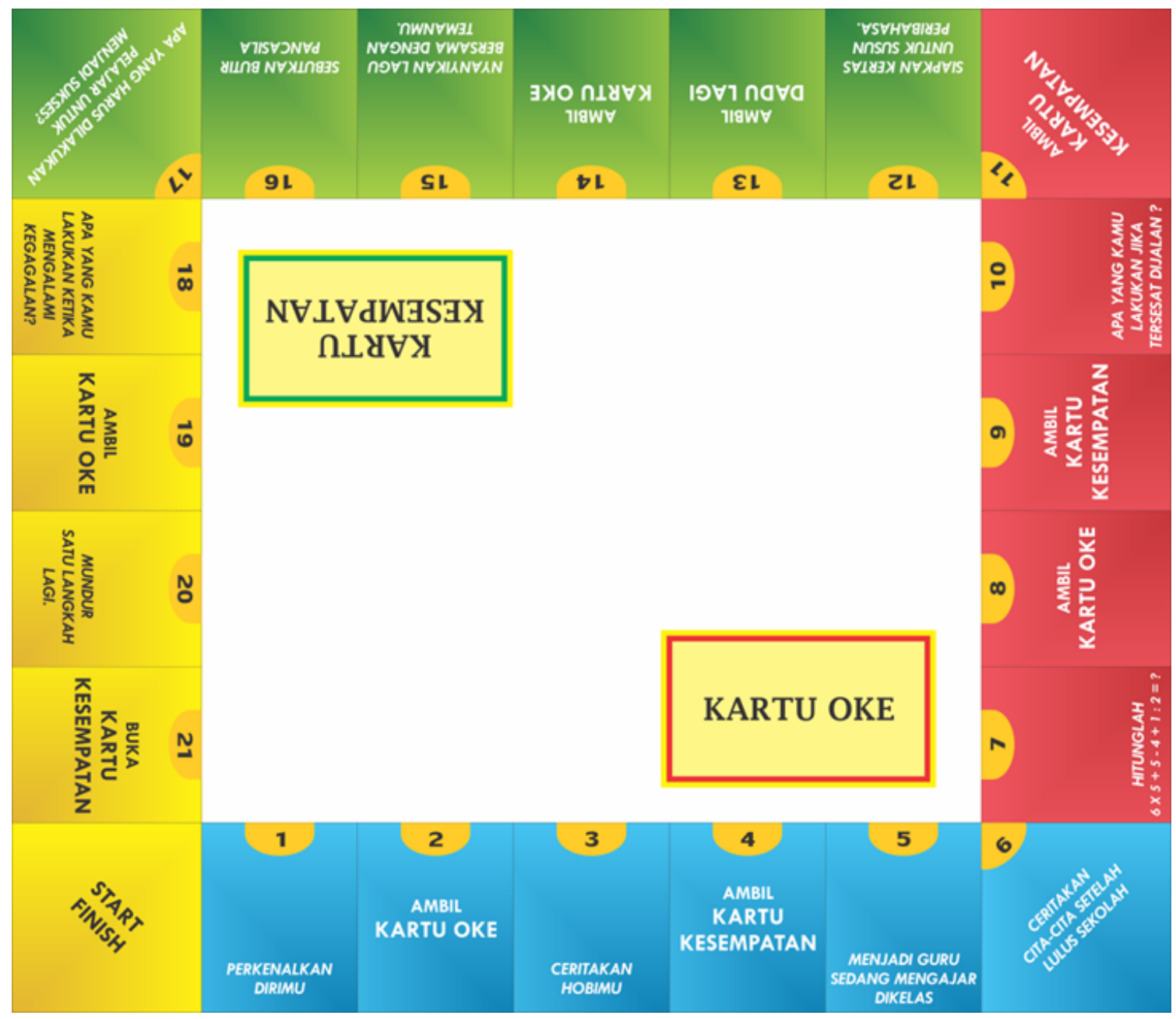

Gambar 1. Beberan 

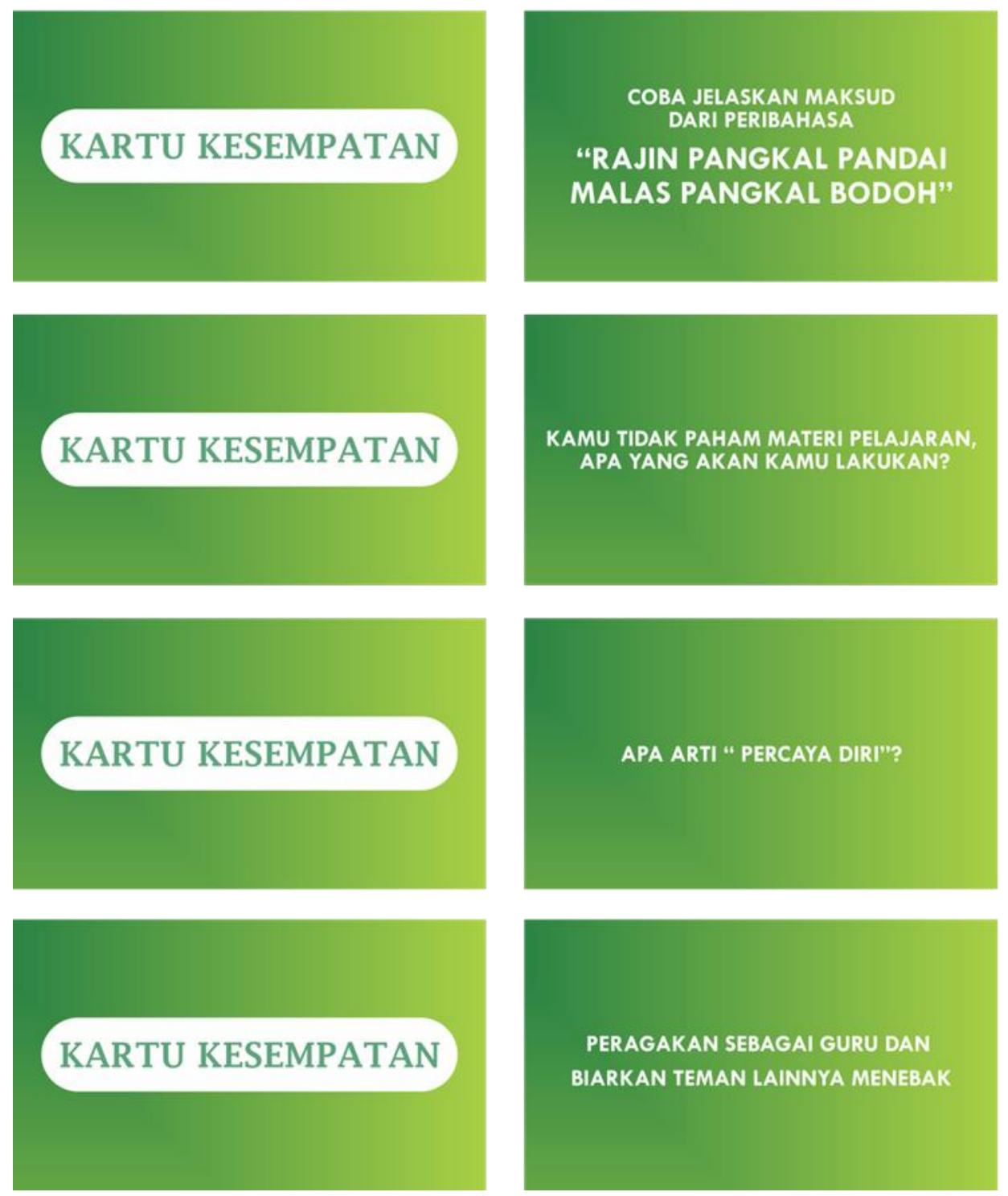

Gambar 2. Kartu Kesempatan 

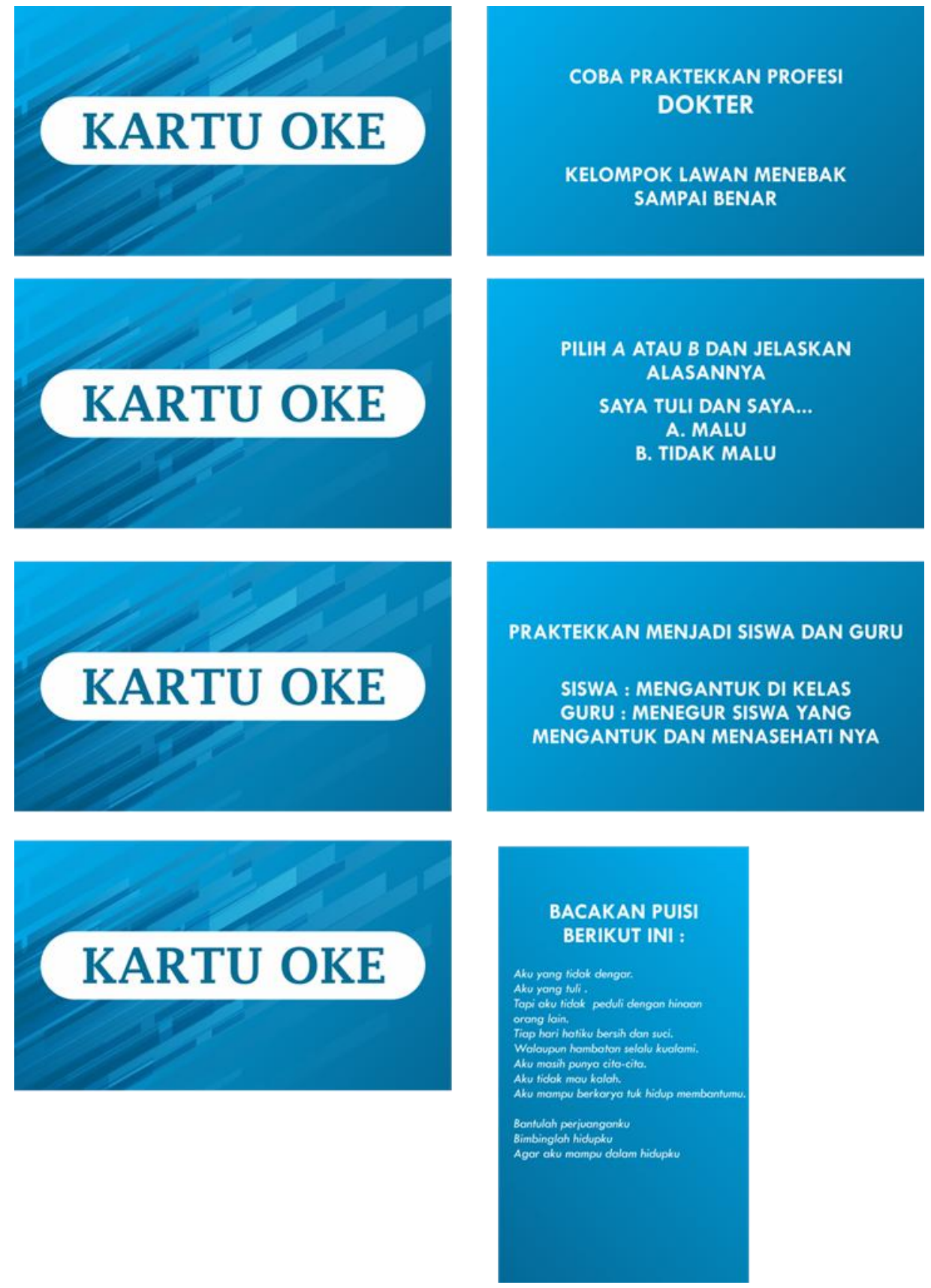

Gambar 3. Kartu oke

Bimbingan kelompok teknik permainan simulasi dilakukan dengan 4 tahap. Tahap pertama adalah tahap pendahuluan, pada tahap ini peneliti dengan didampingi guru SLB memulai kegiatan dengan mengucapkan salam terlebih dahulu kemudian berdoa, dilanjutkan dengan memaparkan definisi dari kegiatan bimbingan kelompok yang akan dilakukan. Lalu menjelaskan teknis atau cara permainan serta hal-hal yang harus diperhatikan selama kegiatan berlangsung. Tahap kedua adalah tahap peralihan, peneliti melakukan ice breaking untuk membangun dinamika kelompok serta membangun minat siswa dalam mengikuti kegiatan. Tahap ketiga adalah tahap kegiatan, tahap ini adalah tahap inti dalam bimbingan kelompok, masing masing pemain memilih pionnya yang diletakkan dalam kotak start dalam beberan Urutan pemain ditentukan berdasarkn suit yang dilakukan antar pemain. Pemain yang mendapat giliran pertama akan mengocok dadu dan melempar dadu tersebut. Pemain harus menjalankan pion sebanyak mata dadu yang keluar ketika dilempar. Pemain melakukan kegiatan yang disesuaikan dengan arahan yang terdapat di beberan, arahan tersebut bervariasi salah satunya 
adalah harus mengambil kartu kesempatan, setelah mengambil kartu kesempatan, pemain harus melakukan kegiatan yang diinstruksikan dalam kartu kesempatan yang telah dipilihnya. Pemain harus melakukan kegiatan yang diinstrusikan dalam kartu kesempatan tersebut dengan baik dan tuntas karena akan dinilai oleh peneliti. Begitu seterusnya hingga seluruh pemain mendapat giliran untuk melemparkan dadu. Pemenang permainan ditentukan dari pion yang terlebih dahulu sampai pada garis finish. Tahap terakhir adalah tahap penutup. Peneliti mengulang kembali beberapa arti kosakata yang telah dipelajari dalam tahap kegiatan, lalu peneliti meminta masing masing pemain mengemukakan kesan setelah melakukan kegiatan, setelah itu peneliti menutup kegiatan bimbingan kelompok teknik permainan simulasi dengan mengucapkan salam dan memberikan ucapan terimaksih pada siswa.

Selama proses perlakuan terlihat antusiasme yang tinggi dari para pemain peran, siswa tidak sungkan untuk bertanya pada peneliti tentang teknis permainan simulasi yang dilakukan, ini artinya proses belajar yang dilakukan dengan teknik permainan dapat meningkatkan antusiasme siswa dalam belajar. Hal ini sejalan dengan hasil penelitian yang dilakukan oleh Ninda Ayu Putri Cahyani; Khairul Bariyyah; Leny Latifah, (2017) hasil penelitian tersebut menemukan fakta bahwa teknik permainan simulasi dengan menggunakan media dart board menimbulkan rasa ketertarikan siswa terhadap proses pelajaran sehingga secara tidak langsung menimbulkan rasa penasaran pada siswa untuk memperhatikan dan memunculkan keinginan untuk mengikuti pelajaran dengan seksama.

Hasil observasi yang dilakukan peneliti juga menemukan beberapa hal lain ketika melakukan proses perlakuan pada kelas eksperimen yakni siswa terlihat sangat berusaha untuk memahami instruksi yang diberikan peneliti lalu siswa berusaha memahami kalimat yang diucapkan oleh lawan main dalam proses bimbingan kelompok teknik permainan simulasi. Siswa memainkan beberapa peran yang diarahkan oleh peneliti, siswa juga melakukan beberapa pengembangan peran hasil dari kreatifitas masing-masing siswa. Selain itu peneliti menemukan bahwa minat siswa untuk belajar kosakata baru melalui peran yang dimainkan meningkat hal ini ditandai dengan tingginya antusiasme siswa dalam bermain peran, tingginya usaha yang dilakukan oleh siswa untuk memahami tiap kalimat yang diucapkan lawan main dalam permainan peran, siswa melakukan beberapa alternative untuk menunjang dalam memahami kata yakni dengan menggunakan media kertas, siswa berusaha melakukan komunikasi dengan menggunakan kata-kata yang sebelumnya belum dipahami, kemampuan siswa dalam memahami kata bertambah sehingga mendukung proses komunikasi reseptif.

Bimbingan kelompok teknik permainan simulasi dapat dijadikan salah satu alternative bagi guru untuk mengenalkan beberapa kata yang biasa dipakai sehari-hari. Semakin bertambahnya jumlah kosakata yang dikuasai akan menunjang kemampuan siswa dalam melakukan komunikasi reseptif. Hal ini senada dengan penelitian yang dilakukan oleh (Hidayat, 2017) kemampuan kosakata tersebut akan membuat anak mengerti terhadap lingkungan dan informasi yang didapat baik secara visual atau auditif. Kekayaan kata yang dimiliki anak akan berdampak pada kemampuan untuk mengekspresikan diri bagi anak tunarungu. Pada akhirnya dengan modal perbendaharaan kata yang memadai akan membuat anak lebih mampu untuk berkomunikasi dan mengungkapkan gagasan dan ekspresi diri melalui bicara. Kegiatan belajar siswa tunarungu harus disesuaikan dengan keterbatasan siswa tunarungu tersebut, agar pembelajaran khususnya kemampuan komunikasi reseptif dapat ditingkatkan. Salah satu media yang dapat digunakan adalah bimbingan kelompok teknik permainan simulasi, karena di dalamnya banyak terdapat gambar dan efek visual yang mendukung siswa tunarungu untuk memahami arti suatu kalimat yang panjang. Selain itu juga menggunakan benda-benda kongkrit yang dapat mendukung dalam proses pembelajaran. Ini relevan dengan prinsip-prinsip pembelajaran khusus bagi siswa tunarungu.

Untuk membuktikan hipotesis bahwa bimbingan kelompok teknik permainan simulasi berpengaruh terhadap peningkatan komunikasi reseptif siswa tunarungu di SLB.B Wiyata Dharma 1, digunakan analisis Mann Whitney U Test. Berdasarkan uji Mann-Whitney U Test diperoleh Asymp.Sig. (2-tailed) 0,013 dengan taraf kesalahan 0,05 maka 0,013 < 0,05 artinya Ho ditolak dan Ha diterima yaitu perbedaan yang signifikan antara kelompok kontrol dengan kelompok eksperimen. Berdasarkan hasil yang signifikan tersebut dapat dikatakan bahwa bimbingan kelompok teknik permainan simulasi dapat dijadikan sebagai salah satu alternatif dalam membantu siswa tunarungu belajar mengartikan ungkapan-ungkapan dan kata-kata yang abstrak (idiomatik), berlatih memahami kalimat-kalimat yang panjang, berlatih memahami arti kiasan, menambah kosakata baru, yang pada akhirnya dapat menjadi solusi bagi kesulitan siswa tunarungu dalam berkomunikasi. 


\section{KESIMPULAN}

Dari hasil pretest dan posttest dapat diketahui bahwa skor mean kelompok eksperimen mengalami kenaikan dari 104 menjadi 124. Hasil pretest kelompok eksperimen menunjukkan peningkatan kategorisasi kemampuan komunikasi reseptif, yakni 1 siswa meningkat dari kategori rendah ke sedang dan 1 siswa meningkat dari kategori sedang ke tinggi. Bimbingan kelompok teknik permainan simulasi ini terdiri dari 4 tahap yaitu tahap pembentukan, tahap pengalihan, tahap kegiatan dan tahap penutup. Selama pelaksanaan bimbingan kelompok, terlihat antusiasme yang tinggi dari para siswa. Siswa tidak sungkan untuk bertanya pada peneliti tentang teknis permainan simulasi yang dilakukan, siswa terlihat sangat berusaha untuk memahami instruksi yang diberikan peneliti lalu siswa berusaha memahami kalimat yang diucapkan oleh lawan main dalam proses bimbingan kelompok teknik permainan simulasi. Siswa memainkan beberapa peran yang diarahkan oleh peneliti sesuai dengan yang ada di dalam kartu oke dan kartu kesempatan. Siswa juga melakukan beberapa pengembangan peran hasil dari kreatifitas masing-masing siswa. Selain itu peneliti menemukan bahwa penguasaan kosakata baru melalui peran yang dimainkan meningkat hal ini dilihat dari meningkatnya skor pretest dan posttest pada kelompok eksperimen, selain itu juga dapat dilihat dari kemampuan siswa dalam memahami instruksi yang tertulis di kartu oke dan kartu kesempatan, kemampuan siswa untuk menjawab pertanyaan yang ada di kartu serta dari hasil uji mann whitney test diperoleh Asymp.Sig. (2-tailed) 0,013 dengan taraf kesalahan 0,05 maka 0,013 $<0,05$. Berdasarkan hasil yang signifikan tersebut dapat dikatakan bahwa bimbingan kelompok teknik permainan simulasi dapat dijadikan sebagai salah satu alternatif dalam membantu siswa tunarungu untuk meningkatkan komunikasi reseptif.

\section{REFERENSI}

Anita Dewi Astuti, Sugiyo, S. (2013). Model Layanan Bk Kelompok Teknik Permainan (Games) Untuk Meningkatkan Keterampilan Komunikasi Interpersonal Siswa. Jurnal Bimbingan Konseling (Semarang), 2(1), 50-56. https://doi.org/10.15294/jubk.v2i1.1236

Efendi, M. (2009). Pengantar Psikopedagogik Anak Berkelainan. Jakarta: Bumi Aksara.

Fatimah, L. (2012). Pelaksanaan Pengembangan Kemampuan Bahasa Reseptif Dan Bahasa Ekspresif Anak Tunarungu Kelas Tk 1 a Studi Deskriptif Di Lpatr Pangudi Luhur, Kembangan Jakarta Barat. JPK : Jurnal $\begin{array}{lllll}\text { Pendidikan } & \text { Khusus, } & \text { 1(01), } & \text { 48-56. } & \text { Retrieved }\end{array}$ http://journal.unj.ac.id/unj/index.php/jpk/article/view/5743

Fillina, Z. (2013). Efektivitas Metode Role Playing Untuk Meningkatkan Kosakata Anak Tunarungu. 1, 311318.

Hallahan, D. P. \& Kauffman, J. M. (1991). Exceptionality Childern Introduction to Special Education ((fifth ed.). New Jersey: Prentice Hall International, Inc..

Hernawati, T. (2007). Pengembangan Kemampuan Berbahasa Dan Berbicara Anak Tunarungu. Juni, 7(1), 101110. https://doi.org/10.1111/j.1464-410X.2011.10525.x

Hidayat, R. (2017). Peningkatan Perbendaharaan Kata Anak Tunarungu Pada Kelas 1 Melalui Pembelajaran Pendekatan Kontekstual. Jurnal Widia Ortodidaktika, 6(1), 85-96.

Mutiara, I. M. (2013). Penggunaan Media Komunikasi Visual Dalam Meningkatkan Bahasa Reseptif Anak Tunarungu. Universitas Pendidikan Indonesia.

Ninda Ayu Putri Cahyani1; Khairul Bariyyah2; Leny Latifah3. (2017). Efektivitas Teknik Permainan Simulasi dengan Menggunakan Media Dart Boarduntuk Meningkatkan Motivasi Belajar Siswa Kelas VIIC SMP Negeri 2 Tegal Siwalan Probolinggo. Jurnal Konseling Indonesia, 3(1), 1-27. Retrieved from http://ejournal.unikama.ac.id/index.php/JKI/article/view/1975/1551

Prayitno. (2004). Layanan Bimbingan dan Konseling Kelompok (Dasar dan Profil). Jakarta: Ghalia Indonesia.

Pujiwati, S. (2012). Pemahaman, Meningkatkan Benda, Kosakata Melalui, Tunarungu Maternal, Metode Di, Reflektif. JASSI_anakku, 1, 142-151.

Rachmawati. (2017). Flash Card. JASSI_anakku, 18(2003), 63-69. https://doi.org/10.2307/j.ctv6wghfz.17

Romlah, T. (2013). Teori dan Praktek Bimbingan dan Konseling (Malang). Universitas Negeri Malang Press.

Rusmana. (2009). Bimbingan dan Konseling Kelompok di Sekolah. Bandung: Rizkqi Press.

Sari, P. N. P., \& Praherdhiono, H. (2014). Pengaruh Penggunaan Metode Maternal Reflektif Terhadap Keterampilan Membaca Permulaan Siswa Tunarungu Kelas III SDLB. Jurnal Ortopedagogia, 1(3), 217224.

Somad, P. (2016). Teori Ekologi sebagai Dasar Pengembangan Keterampilan Komunikasi Siswa Tunarungu Usia Pra-Sekolah. Jassi Anakku, 12(1), 97-111.

Suparno. (2001). Pendidikan Anak Tunarungu(Pendekatan Orthodidaktik). Yogyakarta: Universitas Negeri Yogyakarta. 
Syarah Aini Fajrin, \& Hernawati, T. (2018). Media Komik Untuk Melatih Kemampuan Membaca Pemahaman Pada Siswa Tunarungu. Jassi Anakku, 18(2), 63-69.

Tarmansyah. (2014). Perkembangan Bahasa Dan Komunikasi Pada Anak Usia Dini. Yogyakarta: Universitas Negeri Yogyakarta.

Witri Erdiawati S.R, B. S. (2016). Counter Balance. JASSI_anakku, 18(2), 1-5. 